\title{
AN UIGUR DECREE OF TAX EXEMPTION IN THE NAME OF DUWA-KHAN
}

DAI MATSUI

\section{Introduction}

Prof. Dr. Reşid Rahmeti Arat, the great Turkish scholar in the field of Old Turkic philology, dealt with great number of the Old Uigur secular documents in the German-Turfan collection during his study at Berlin from 1928 to 1933. Meanwhile he made many photographic reproductions of the Uigur documents for his further researches, and took the photographs with himself back to Istanbul. Quite a number of the originals of those Uigur documents were destroyed during the World War II, and then the photographs taken by Arat have the great importance to enable us to view the loșt manuscripts (Sertkaya, 1996: 279-281).

The Uigur decree presented in this paper also belongs to the lost Berlin collection. It is mentioned by Arat under his personal inventory number "77/01" (Arat, 1964: 16), but he only placed a brief summary. Recently I had a fortune to be offered from Prof. Dr. Osman Fikri Sertkaya (Institute of Turkic Studies, Istanbul University) the photograph taken by Arat with the permission to use it for research, and I have mentioned to its contents in my previous articles (Matsui, 2005: 72; Matsui, 2007a: 67). Here I would like to provide fully annotated edition of the document with the photograph, as well expressing my sincere gratitude to Prof. Sertkaya for his kindness.

From the photograph, we can observe the site-number "T III Murtuq 253" written on the upper-right of the document, which tells us that it was brought by the Third German Expedition (1906-1907) from the site Murtuq. Unfortunately, we have no information of size or color of the document, though visible are four of vertical and three horizontal fold lines. A rectangle seal is stamped on ${ }^{9}$ törüsin and ${ }^{10}$ yorïqü, but the inscription is too obscure to decipher (see Chapter 6 below). The photograph shows another document fragment aside, on which we find a large Brahmi (or 'Phags-pa?) character. According to Prof. Sertkaya, Arat took the two manuscripts into a single flame and the fragment has no direct connection with our decree.

\section{Text}

01 țuw-a yrlq-ïn-tïn 
02

03

04

05

06

07

08

09

10 [t](ü)män sözüm tü[kä](1)-a adań-a ikigü-kä. aḍangïz-lar

qodmïš bitigni yorịḍmayïn qalan birim alïm

tip tarḍar ärmiš șiz-lär bu altmïš-a qy-a-

-nïng oq [ü]ntürmiš bitiginčä,qalan qayuḍ

birim alïm tilämäng-lär anasïn- $\gamma$ a tapïnïp

yorïșun tip bitig birtim • qalančì

alïm-čï m-ä bolsar altmïš-a-tïn tilämänglär

barẓ yïl aram ay otuz-qa il törüsin-

-čă aḍasï buyań-a-nïng bitigi yorïqï üčün

\section{English Translation}

${ }^{01}$ By Duwa's edict. ${ }^{02}$ Tümän, my word (i.e. decree). To the two of Tükälä and Adana.

02-03"We shall not let the document that your fathers (i.e. ancestors) left [for you] pass (i.e. be valid). [Here are] qalan-labor services and birim-alïm-taxes [on you]!", ${ }^{04}$ thus saying, you have taken [from] (i.e. imposed taxes and labor services on) [Altmïša-Qya].

${ }^{04-05}$ According to the document that this Altmïša-Qya just presented, ${ }^{05-06}$ never charge qalan-qayut-labor services nor birim-alïm-taxes [on Altmïša-Qya]! ${ }^{06-07}$ Just let him pass in serving his mother! Thus saying, I gave [this] document. ${ }^{07-08}$ Even if [Altmïš-Qya] should be qalan-labor worker or alïm-tax payer, never charge on Altmïša[-Qya]!

${ }^{09} \mathrm{On}$ the $30^{\text {th }}$ day, the $1^{\text {st }}$ month, the year of Tiger. ${ }^{09-10}$ For the validity of the document of his (i.e. Altmïa-Qya's) father Buyana according to the law of the country.

\section{Notes}

01, țuw-a yrlq-ïn-tïn: This phrase clearly shows that the document was issued under the authority of the Chaghataid khan Țuw-a $\sim$ Duwa Du'a (> Pers. Dü'ā, r. 1282-1307). Duwa had allied with the Ögödeid prince Qaidu (1236-1301) in the military activities against the Yuan dynasty, but after his death swept the Ögödeids in Central Asia to finally re-establish the hegemony of Chaghataid khanate (Biran, 1997: 69-77). His name is written in the same form TWW-' as here in the inscription in memory of the Uigur Ïduq-quts (Geng / Hamilton, 1981: 16, 18), while as TWQ-' = Dur- $a$ in the Mongolian letter of AD 1304 by the Ilkhan Öljeitü (Mostaert / Cleaves, 1962: 55).

The phrase as XX yrlq-ïn-tïn "by the edict of XX", composed of yrlq yarliq "edict" 
with $+\ddot{m}$ (instructive) $+\operatorname{tin}$ (locative-ablative), is attested in the Persian decrees issued by the Ilkhanate (Herrmann, 2004: 14), and it should be the corresponding to Mong. XX jarliy-iyar "by the edict of XX", the typical opening phrase in the administrative documents (Matsukawa, 1995b: 40). In the Mongol times, jarliy "edict" is used only for the edict of the Yuan emperors, while üge "word" is used for decree or commands of the other princes, princesses, nobles, ministers, etc. (Sugiyama, 1990: 1; Matsukawa, 1995b: 26). Neither Chaghataid khans nor the Ilkhans used the word jarliy but üge for their own decrees, though their subordinate officials or local inhabitants did not hesitate use the word jarliy for the decrees from their rulers regarding them as standing at parity with the Yuan emperors (Matsui, 2007b).

02a, tümän: Uig. tümän (= Mong. tümen) means "ten thousand", then "the leader of the (military or administrative) unit of ten-thousand", and we have some attestation of tümän bägi or tümän noyïn "the leader of ten-thousand-unit" in the Uigur texts (Matsui, 2003: 58-59). Here this Tümän is the name of the issuer, yet it might reflect that he was the tümän-bägi (or tümän-noÿ̈n) in the Turfan region.

02b, tükäl-a adan்-a: They are whom the issuer, Tümän, informed about the contents of the document.

02c, aḍangïz-lar: Arat took this "your fathers" as those of Tükälä and Adana (Arat, 1964: 16), though from the context we should regard as Altmīša-Qya's fathers (i.e. ancestors) and understand the text adangïz-lar qodmïs bitigni yorïdmayïn as the claim by Tükälä and Adana in their imposing tax on Altmïša-Qya.

03, qalan birim alïm: Here qalan and birim alïm are' used as generic terms for all kind of taxes and labor services (Matsui, 2005: 72). In a narrow sense, qalan is a labor service corresponding to Mong. alban or Chin. 差役 chai-yi, and levied on the laymen according to the land in their possession, while it was used also as a generic term for several kind of labor services (Matsui, 2004: 20-21; Matsui, 2005: 72-73). Uig. birim alïm is also a common idiom for basic land tax paid in produce, which covers several subcategories (Matsui, 2005: 72, 74).

04, altmǐs-a qy-a: The demunitive $q y$ - $a$ is omitted in line 08 .

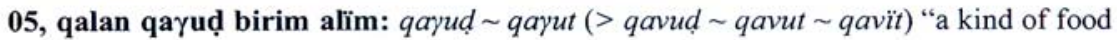
made of millet" has been attested in an idiom qalan qavït in three Uigur documents (Zieme,

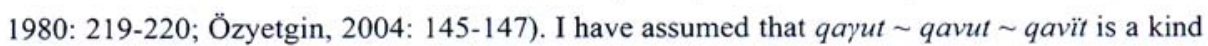
of labor service to be included in qalan as a generic term (Matsui, 2005: 73). Our document also lends support to me, since it refers to both of qalan and qayut here, while in lines 03, omitting qayut, only qalan is mentioned. See also Note $\mathbf{0 3}$ above.

09-10: The tops of these two lines are further lowered than lines 03-08. Here is recorded the date of issuing, and then a "postscript" declares the reason of issuing. 
the influence of the Mongolian chancellery practice, we can pick up as follows: Toqtamišs's decree of 1393 (Özyetgin, 1996: Al); Temür-Qutluy's of 1397 (Özyetgin, 1996: AII); Šāh-Rub's of 1422 (Deny, 1957; Ono, 2006); Sultan Umar-Šayh's of 1469 (Melioranskij, 1904). However, all of the four are from the post-Mongol times, while our document clearly belongs to Duwa's reign (1282-1307) or the Mongol times. Consequently, our document is the oldest Uigur-Turkic decree of the Mongolian chancellery formula so far as ever known.

On the other hand, we can observe the difference in the ending formula. Most of the Chinggisid Mongolian edicts and decrees declare the issuing place after the date at the end (Cerensodnom / Taube, 1993: 166; Matsukawa, 1995b: 44), while our document does not mention. In other words, the officers and the inhabitants to read this decree knew the issuing place so well that they did not mention it: Most probably, it was Qara-Qočo, the main capital of the Turfan region.

\section{Chaghataid Domination of Turfan}

The Qočo Uigur Kingdom in the Turfan region brought itself under the domination of the Mongol empire at the beginning of the $13^{\text {th }}$ century. Since the later half of the century the Turfan region became of the border between the Mongol-Yuan dynasty in China and the Anti-Yuan Ögödeid and Chaghataid princes headed by Qaidu. According to the Persian historian Rašīd al-Dīn (d. 1318), the Uigurs of Qara Qočo or Turfan region were "on good terms with them both and render service to both sides" in the end of Qubilai's reign (Boyle, 1971: 286).

After this period of neutrality, the Turfan region finally fell into the actual domination by the Chaghataids, who had established the independence in Central Asia after Qaidu's death (Allsen, 1983: 258-261; Biran, 1997: 43-44). The official map of AD 1330 compiled by the Yuan court recognizes that Wei-wu-er-di "the land of the Uigurs" including Qara-Qočo, Lükčüng, Biš-Balïq belongs to the Chaghataid khan Döre-Temür (Liu, 2006: 576-590). Still earlier, in 1326, the Chaghataid khan Kebeg issued a decree to a governor in Turfan, which is the oldest one issued by the Chaghataid khanate as hitherto dated fFranke, 1962: 406; - Cerensodnom / Taube 1993: Nr. 76). Moreover, an Uigur petition to the Chaghataid khan Tuyluy-Temür (1346-63) refers to levy of qalan-labor service in Turfan during Esen-Buqa's reign, 1310-1318 (Arat, 1937). These documents suggest that the Chaghataid domination in Turfan had begun by the late 1320 's.

Our decree throws a new light on the beginning of the Chaghataid domination in the Turfan region. It confirms that during Duwa's reign, 1282-1307, his authority was certainly effective among the Uigurs in Turfan. It may give a support to dating of the Chaghataid 
P'RZ = barz instead of P'RS = bars "tiger" may be a reflection of the Mongolian orthography (cf. Yamada, 1993: Sa10, Mi02). Even though there are only two candidates for bars yïl "the Year of the Dragon" during Duwa's reign, i.e. AD 1290 and $1302 \mathrm{AD}$, unfortunately we have no definite clue for final decision.

The postscript might be an influence by the Mongolian chancellery practice. We have some Mongolian decrees that carry the postscript of the reason of issuing, e.g. XX tula "For XX”.

10, yorïqï: Reading as YWRWXY = yoruqï is also possible. Uig. yorïq is a deverbal noun from v. yori- "to go, pass" and usually translated as "course, behavior, character; way of progressing, life" (Clauson, 1972: 963; Erdal, 1991: 257). However, here we should follow Arat's translation as "validity (yürürlük)" (Arat, 1964: 16). Cf. yorïq böz "passable (i.e. valid in commerce) cotton cloth" in Yamada, 1993: Sa07.

\section{Formula of the Document}

Most of the Uigur secular documents - contracts, decrees and administrative orders - give their date at the beginning (Mori, 1961: 115-117; Yamada, 1967: 87-89; Zieme, 1981: Text A; Matsui, 1998: 1). From this viewpoint, the Uigur decree presented here is rather rare one that gives its date at the end. I have already noted that it should be influenced by the contemporary Mongolian chancellery practice (Matsui, 2007a: 67).

Furthermore, we can easily find that the formula of our decree parallels with that of the edicts or decrees by the Chinggisid Mongolian emperors or princes. According to the terms of the Mongolian decrees from Turfan and China (Cerensodnom / Taube, 1993: 165-167; Matsukawa, 1995b: 36-44), we may summarize the contents of our decree as follows:

(1) Autorisierung (01): Duwa, the Chaghataid ruler.

(2) Intitulatio (02): Tümän, seemingly the high-ranked governor in the Turfan region.

(3) Publicatio (03): Tükälä and Adana, apparently the local officers (bägs) in the Turfan region under Tümän.

(4) Narratio (02-04): Unlawful levy of qalan-labor and birim-alïm-taxes on Altmïša-Qya by Tükälä and Adana.

(5) Inscriptio: Altmǐš-Qya

(6) Dispositio (04-08): Re-authorization of exemption from taxes and labor services, which had been, bestowed Altmïša-Qya and his family.

(7) Schlußprotkoll: The date and the reason of issuing.

As the Turkic administrative decrees in Uigur script that follow such a formula under 
occupation of Turfan to the first years of the $14^{\text {th }}$ century (e.g. Allsen, 1.983:259).

However, a close observation on the format of the decree does not allow such simplified understanding on the historical situation in that period.

First, the Chaghataid khans and their subject officials adopted a mark shaped like double-leaves, which is so-called "Chaghatai-Zeichen", in their seals (Franke, 1962). Such seals with "Chaghatai-Zeichen" became popular also among the local Uigur officers of the Turfan region in the mid-14 $4^{\text {th }}$ century (Matsui, 1998: 3-5, 8-9; Matsui, 2002: Texts A, B). Contrarily the seal on our decree apparently does not have the "Chaghatai-Zeichen"

Second, the Chaghataid subordinate officials often used the "Chaghataid honorific style", a typical style in writing administrative documents. As a mark of respect for the authority of the document (i.e. the Chaghataid ruler) at the first line, they lift down the top of the following lines 2-4/5. Also, when "holy" words - e.g., qan "king", oylan "prince", tngri "heaven, god", the names of the high government officials, or others concerning them appear in the text, the top of the following two or three lines are to be laid down for the same reason (Cerensodnom / Taube, 1993: 167; Matsukawa, 1995a: 112-115). Otherwise the top of the lines are at same level with the top of the first line with the name of the Chaghataid ruler (Cerensodnom / Taube, 1993: Nrn. 68, 70, 71, 72, 74, 76; Dunhuang North B163:42 = Matsui, 2007b). Uigur local officers in Turfan also adopted this method (Matsui, 1998: 8-11, 18-19, 27-28). From this point of view, our decree lifts up the name of the ruler $\left({ }^{01}\right.$ Duwa) to the highest and the name of the governor $\left({ }^{02}\right.$ Tümän) to the next, and keeps the top of following lines beneath, seemingly following another style of chancellery practice than the Chaghataids'.

Summing up, we may conclude that during Duwa's reign the Chaghataid domination in Turfan was not thoroughgoing enough to influence the local chancellery system. It tallies that the six Uigur administrative orders so-called "Yalïn-texts", which are dated to during 1319-1322, have no sign of the Chaghataid domination (Matsui, 2003: 53-55).

Yet, it should be noted that the issuer of our decree, Tümän, seemingly the contemporary governor of the Turfan region, disregards the Yuan-emperor but regards the Chaghataid ruler Duwa at the beginning. Our decree must be a new source to witness that the Yuan domination in Turfan was on a decline during Duwa's reign. 


\section{References}

Arisen, T. T., (1983), "The Yuan Dynasty and the Uighurs of Turfan in the 13th Century", M. Rossabi (ed.) China among Equals, Berkeley / Los Angels / London: University of California Press. 243-280.

Arat, R. R., (1937), 'Uygurca yazilar arasinda', Tiirk Tarih, Arkeologya ve Etnografya Dergisi, 3 [1936], 101-112,+1 pi.

Arat, R. R., (1964), “Eski Tiirk hukuk vesikalan”, Turk Kiilturii Ara§̧tirmalan, 1, 1 53.

Biran, M, (1997), Qaidu and the Rise of the Independent Mongol State in Central Asia. Richmond: Curzon. $x+198$.

Boyle, J. A., (1971), The Successors of Genghis Khan. New York: Columbia University Press: $372+2$.

Cerefisodnom, D., / Taube, M., (1993), Die Mongolica der Berliner Turfansammlung. Berlin: Akademie Verlag: 230+57.

Chen, G., (1982), "Miscellanous Notes on Xinjiang in the Yuan Period", The Second Volume of Studies on the History of Xinjiang, Urumqi: Xinjiang Renmin

Chubanshe: 274-294. Clauson, G., (1972), An Etymological Dictionary of PreThirteenth-Century Turkish. Oxford: Clarendon Press: xlviii+989.

Deny, J., (1957), "Un soyurgal du timouride Sahruh en ecriture ouigoure”, Journal Asiatique, 245, 253-266.

Erdal, M., (1991), Old Turkic Word Formation, Vol. I-II. Wiesbaden: Harrassowitz: 874.

Franke, H., (1962), "Zur Datierung der mongolischen Schreiben aus Turfan", Oriens, $15,399-410$.

Geng, S., / Hamilton, J. R., (1981), "L'inscription ouigoure de la stele commemorative des Iduq qut deQoco", Turcica, 13, 10-54.

Herrmann, G., (2004), Persische Urkunden der Mongolenzeit. Wiesbaden: Harrassowitz: 327.

Liu, Y, (2006), Studies on the History of the Chaghataid Khanate. Shanghai: Shanghai Guji Chubanshe: 635.

Matsui, D., (1998), "Uigur Administrative Orders Bearing Qutluy-seals", Studies on the Inner Asian Languages, 13, 1-62,+15 pis.

Matsui, D., (2002), "Taxation and Tax-collecting Systems in Uiguristan under Mongol Rule", K. Matsuda (ed.) Research on Political and Economic Systems under Mongol Rule. Osaka: Osaka International University. 87-127.

Matsui, D., (2003), "The Yalin-Texts. Six Uigur Administrative Orders from the Early Fourteenth Century", Hirosaki University Studies in the Humanities (Cultural Sciences), 10, 5.1-72. Matsui, D., (2004), "Uigur Peasants and Buddhist Monasteries during the Mongol Period”, Toyoshi Kenkyu, 63(1), 1-32. 
Matsui, D., (2005), "Taxation Systems as Seen in the Uigur and Mongol Documents from Turfan: An Overview", Transactions of the International Conference of Eastern Studies, 50, 67-82.

Matsui, D., (2007a), "An Uigur Document Preserved in the Library of Istanbul University", Studies on the Inner Asian Languages, 22, 61-70.

Matsui, D., (2007b), "A Mongolian Decree from Chaghataid Khanate Discovered at Dunhuang". P. Zieme (ed.) Aspects of Research into Central Asian Buddhism, in Memoriam Kogi Kudara. Turnhout: Brepols. (in press)

Matsukawa, T., (1995a), Review of D. Cerensodnom / Taube, Die Mongolica der Berliner Turfansammlung, 1993. Toyoshi Kenkyu, 54(1), 105-122.

Matsukawa, T., (1995b), "On the Daiyuan-Ulus Style in the Mongolian Edicts of the 13th and 14th Centuries", Machikaneyama Ronso, 30, 25-52.

Melioranskij, R., (1904), "Dokumenf ujgurskago pis'ma sultana Omar'-Shejkha", Zapiski Vostochnago Otdelenija Imperatorskago Russkago Arkheologicheskago Obshchestva, 16(1), 1-12.

Mori, M., (1961), "A Study on Uygur Documents of Loans for Consumption", Memoirs of the Resaerch Department of the Toyo Bunko, 20, $111-148$.

Mostaert, A., / Cleaves, F. W., (1962), Les lettres de 1289 et 1305 des ilkhan Aryun et Oljeitu a Phillip le Bel. Cambridge (Mass.): Harvard University Press: $\mathrm{vi}+104+12$.

Ono, H., (2006), "Revision of the Uigur-Turkic Decree Issued by Timurid Sahruh", T. Horikawa (ed.) Historical Studies on Formation and Change of Muslim Communities in Central Asia, Kyoto: Kyoto University of Foreign Studies. 28-47.

Ozyetgin, A. M. (1996), Altin Ordu, Kirim ve Kazan Sahasina Ait Yaflik ve Bitiklerin Dil ve Usliip Ineelemesi. Ankara: Ahc Ofset matbaacihk Sanayi Ticaret: xii+297.

Ozyetgin, A. M., (2004), Eski Tiirk Vergi Terimleri. Ankara: Koksav: XII+250.

Sertkaya, O. F., (1996), "Die Geschichte der im Zweiten Weltkrieg verlorengegangenen und zerstorten uigurischen Texte und das altuigurische Bruchstuck mit Sternnamen". R. E. Emmerick et al. (eds.) Turfan, Khotan und Dunhuang. Berlin: Akademie Verlag. 279-291.

Sugiyama, M., (1990), "A Study on the Inscription of the Sino-Mongolian Edicts in 'Phags-pa Script". Studies on the Inner Asian Languages, 5, 1-31, +2 pis.

Yamada, N., (1967), "Uigur Documents of Sale arid Loan Contracts Brought by Otani Expeditions. Apendix: The Forms of the Uigur Documents of Sale Contracts", Memoirs of the Resaerch Department of the Toyo Bunko, 23 [1964], 71-118, +4 pis.

Yamada, N., (1993), Sammlung uigurischer Kontrakte, 3 vols. Osaka: Osaka University Press: xvii +588+11, xxi+330, viii +160 .

Zieme, P., (1980), "Uigurische Pachtdokumente", Altorientalische Forschungen, 7, 197-245, +Taf. III-XII. 
Zieme, P., (1981), "Uigurische Steuerbefreiungsurkunden fur buddhistische Kloster", Altorientalische Forschungen, 8, 237-263, +Taf. XIX-XXII.

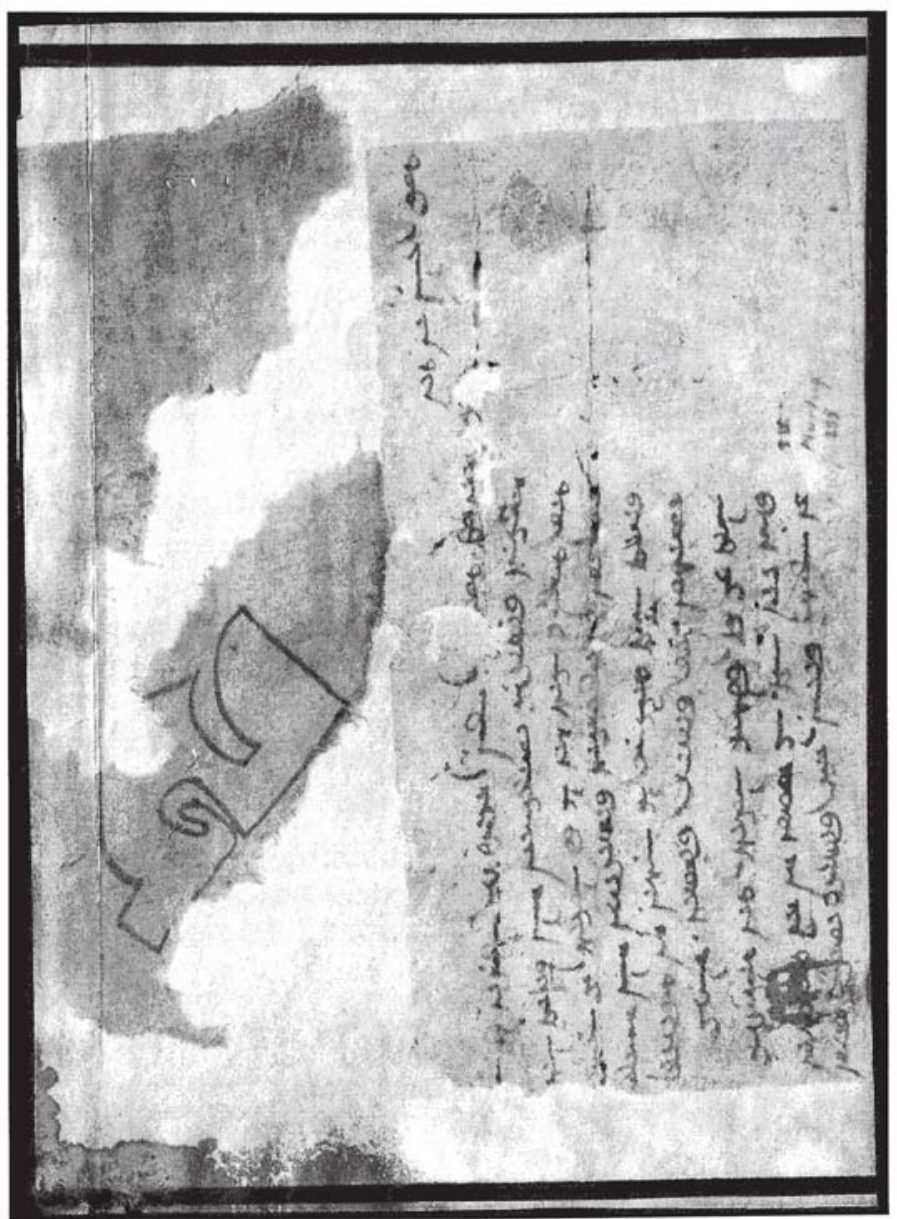

T III Murtuq 253

(By courtesy of Prof. Dr. Osman Fikri Sertkaya) 